\title{
Technological level of the Aerospace Industry of Ensenada, B.C. in its manufacturing processes
}

\author{
Nivel tecnológico de la Industria Aeroespacial de Ensenada, B.C. en sus procesos de \\ manufactura
}

CERVANTES-TRUJANO, Margarita $\dagger^{*}$, ROMERO-SAMANIEGO, Elizabeth and CAMPOSGARCÍA, Josefina

Tecnológico Nacional de México / Instituto Tecnológico de Ensenada Institución

ID $1^{\text {st }}$ Autor: Margarita, Cervantes-Trujano / ORC ID: 0000-0002-8857-9023, CVU CONACYT ID: 121516

ID $1^{\text {st }}$ Coautor: Elizabeth, Romero-Samaniego / ORC ID: 0000-0002-9290-0879, CVU CONACYT ID: 499629

ID $2^{\text {nd }}$ Coautor: Josefina, Campos-García / ORC ID: 0000-0001-6345-2125, CVU CONACYT ID: 277648

DOI: $10.35429 / J I O .2019 .5 \cdot 3.24 .28$

Received May 28, 2018; Accepted June 30, 2018

Resumen

El presente proyecto se realizó con la finalidad caracterizar el nivel tecnológico de la industria aeroespacial de Ensenada, B.C. México., en sus procesos de manufactura para establecer áreas de oportunidad y determinar su impacto en la competitividad. Se llevó a cabo una investigación cuantitativa, de tipo descriptivo para establecer el nivel de automatización, los cuales se aplicaron en encuestas directas en visitas industriales (Ovalle, et al., 2013). Se entrevistaron siete empresas en donde se determinó sus diferentes estrategias para la compra de nuevas tecnologías, incluida la automatización. Se identificó que las empresas adquieren la nueva tecnología a través de proveedores previamente seleccionados y en algunos casos cotizando a nuevos proveedores. La vigilancia tecnológica se realiza preferentemente en catálogos o con la visita de proveedores; también por recomendaciones de los clientes, o visitando ferias o misiones tecnológicas. Se registró que algunas empresas cuentan con la asesoría de centros de investigación y que seleccionan la nueva tecnología mediante los criterios de estandarización y adaptabilidad al proceso, seguido de precio y marca. Los mayores niveles de automatización se registraron en la comunicación, seguido de la etapa de proceso de producción, y la del abastecimiento de materiales.

Aeroespacial, Automatización, Competitividad
Abstract

The present project was carried out with the purpose of characterizing the technological level of the aerospace industry of Ensenada, B.C. Mexico., In its manufacturing processes to establish areas of opportunity and determine its impact on competitiveness. A quantitative, descriptive research was carried out to establish the level of automation, which was applied in direct surveys in industrial visits (Ovalle, et al., 2013). Seven companies were interviewed where it was determined that they have different strategies for the purchase of new technologies, including automation. It was identified that companies acquire the new technology through previously selected suppliers and in some cases quoting new suppliers. Technological surveillance is preferably carried out in catalogs or with the visit of suppliers; also by customer recommendations, or visiting fairs or technology missions. It was recorded that some companies have the advice of research centers and that they select the new technology through the criteria of standardization and adaptability to the process, followed by price and brand. The highest levels of automation were recorded in the communication, production process and the stages of supply of materials.

Aerospace, Automation, Competitiveness

Citation: CERVANTES-TRUJANO, Margarita, ROMERO-SAMANIEGO, Elizabeth and CAMPOS-GARCÍA, Josefina. Technological level of the Aerospace Industry of Ensenada, B.C. in its manufacturing processes. Rinoe Journal-Industrial Organization. 2019. 3-5: 24-28

\footnotetext{
*Correspondence to Author (mctrujano@ite.edu.mx)

$\dagger$ Researcher contributing first author.
} 


\section{Introduction}

The development of the Aerospace Industry in Baja California originated mainly with manufacturing activities. What has generated and maintained a base of more than 200 companies that respond to the requirements of high quality standards and regulatory compliance at the international level. Participating in six segments that are: commercial aviation, defense, space, drones, MRO / R \& O and logistics charge. The same group of companies, from large firms, as well as small and medium-sized subcontractors that have the capacity to manufacture custom production orders (Sibaja, 2019). The city of Tijuana stands out with $49 \%$ of operations, followed by Mexicali with $34 \%$ and the rest is distributed in the municipalities of Ensenada, Tecate and Rosarito.

In the municipality of Ensenada, B.C. 7 companies in the aeronautical sector have been identified, and it has been reported that they have been established in the area for 7 to 15 years. $71.42 \%$ are classified as small businesses and $28.57 \%$ as medium businesses. In its administration system for decision-making for competitiveness, it can be through a board of directors, legal representative, or general manager and in some cases, they depend on the corporate in U.S.A.

The sector in the municipality offers employment to more than 851 workers, where the highest percentage are women (55.4\%). The sector has an outstanding industrial and productive capacity in a wide portfolio of product lines such as rubber seals and molded parts, thermoacoustic solutions, design and manufacture of machinery and tools according to the requirements of international clients (Mandujano et al., 2019).

For the industry in general and for the aerospace sector, the use of technology is necessary to streamline the production process, since they are directly related to productivity and competitiveness. Same that depends on the processes of each company and its products. The technological environment includes the production process, the administrative process, the organization, the procedures, the training of the personnel, and the information (Arias, 1999).
The technological level refers to the degree of automation, which the company has, and it is defined how automated the process is according to the use of machines that follow a predetermined order of operations with little or no labor.

Due to the above, an investigation was carried out in the aerospace companies in the municipality of Ensenada, B.C. to determine the technological level and establish the areas of opportunity that allow to create a synergy between the companies and the academy, to carry out joint work that allows to generate greater productivity and competitiveness in the municipality.

\section{Technological environment}

For the industry in general and for the aerospace sector, the use of technology is necessary to streamline the production process as part of productivity and competitiveness. In the technological environment, production processes, administrative processes, organization, procedures, personnel training and information are considered (Arias, 1999).

Another important aspect to consider is the technological surveillance that refers to observing how the technological, economic, social, commercial environment is developing, which allows the company to be updated and prepared for the probable changes, and thus, anticipate the changes for the Decision making in time to reduce risks. It also refers to the search for new technologies that give value to the process.

\section{Business-academy link}

For innovation and competitiveness, companies need to have information and knowledge that can be generated internally or by linking with universities or research institutes (Tether, 2002). With this link, the benefit of the acquisition and assimilation of new knowledge, technological development, and the increase in the level of skills and abilities of human and social capital is generated. The link with the academy promotes a good innovation system for technological change, increased competitiveness and economic growth (Maqueda, 2006). 


\section{Automation levels}

Automation is defined as the process in which machines follow a predetermined order of operations with little or no labor, using specialized equipment and devices that execute and control manufacturing processes. This is achieved using various devices, sensors, actuators, techniques and equipment capable of observing and controlling all aspects of the manufacturing process (Kalpakjin and Prentice, 2002). The levels of process automation can be varied and are derived from the company's own characteristics, which are generally of an economic and technological nature.

The levels of automation are related to a degree of less human intervention in the process, which is replaced by automated machines. The greater the use of machinery, the greater the degree of automation and vice versa. In manufacturing, automation is implemented from raw material supply, assembly, packaging, packaging, storage and logistics. Also included are the Control and supervision operation, information recording and communication processes.

\section{Methodology}

A quantitative, descriptive research focused on manufacturing companies in the aerospace sector in Ensenada, B.C. The methodological instruments that were used are those described by Ovalle et al (2013), which were applied, through direct surveys in visits to companies. Seven companies were selected directly according to their availability for the study; The information was provided by personnel at the managerial level, designated by the company itself, who had extensive knowledge of the processes and administration of the same.

The surveys were focused to determine the strategies with which the purchase of new technologies is decided and how technological surveillance is carried out. Also to identify if there is any kind of link with academic institutions or research centers and to establish the levels of automation they present in communication, material supply and in the production process.

\section{Results}

\section{Acquisition of new technologies}

Of the seven companies, it was identified that decisions for the purchase of new technology, including automation, are carried out through the legal representative $(28.57 \%)$ or the board of directors $28.57 \%$, followed by the corporate $(14.29 \%)$. While the operations management and maintenance area are not considered for the acquisition of new technologies. It was established that the purchase process is preferably carried out through previous suppliers (71.43\%), followed by bidding (14.29\%), and new suppliers $(14.29 \%)$.

Of the companies interviewed, $71.43 \%$ had automation projects under development, while $28 \%$ were not carrying them out at that time. Of the companies with automation projects, $57.14 \%$ of the projects focused on the production process and $14.29 \%$ on the supply stage. The preference of the total of the companies with respect to the different options of access to the information for the technological surveillance was evaluated. It was found that $71.43 \%$ resort to the internet, $57.14 \%$ participate in fairs and technological missions, $42.86 \%$ consider catalogs or the visit of suppliers, $28.57 \%$ resort to research centers or technology transfer and $14.29 \%$ it takes into account customer information, while none considers patents.

From participation in technology fairs, four companies attend at least one of the exhibitions held in Los Angeles, CA., or in Houston, Texas., Or in Las Vegas, Nevada. and only one company mentioned that they participate in a fair that takes place in Paris, France.

On the other hand, of the two companies that do not participate in the mentioned fairs; The staff of one of them attends a conference in the USA organized by its corporate. While the staff of the other company, only attends fairs that are held nationwide in Tijuana, Mexicali and Guadalajara, Mexico. It also indicates that a company does not participate in any fair. 


\section{Linking with the Academic sector}

Three companies were registered that carry out business-academy linkage for the development of technological projects such as TECNM / I.T.Ensenada, a center in Tijuana or CICESE. On the other hand, a company has its own research center in the corporate USA, and three companies reported that they have no connection with the academy. It was registered that all the companies participate in the programs of professional residences or professional practices for which they receive students from the different academic institutions of the Municipality of Ensenada.

As for the main criteria for the renewal or acquisition of technology, they are indicated in order of importance for the companies, which are: the standardization and adaptability of the process, the guarantee of the machinery, the price, the technical specifications and the scheme of maintenance and / or spare parts, and the brand.

With respect to the aspects that companies take into account for the renewal or acquisition of technology, the production capacity stands out first, followed by the obsolescence of machinery and to a lesser extent flexibility, organizational policy, requests for Customers and quality. With the exception of the organizational policy that is not considered, all aspects were mentioned at least once as important.

The aspects that companies take into account for the automation of their processes, are listed according to the order of importance determined: 1) the increase in production quality, 2) quality, 3) new products, 4) technological modernization, 5) competitive strategy, and 6) process flexibility.

Of the aspects in general that the company knows about its main competitors at national and international level, customers stand out. While the market, processes, products, suppliers and especially technology, factors of importance to companies are not highlighted. Regarding the age range of the machines that are used by the companies, it was determined that 3 companies have $100 \%$ - $80 \%$ of their machinery in a range of 0 to 5 years.
In another company, $90 \%$ of the machinery is in a range between 6 and 10 years, two other companies $60-80 \%$ of its machinery is in the range of 11 to 20 years and only one company has $33 \%$ of its machinery with more than 20 years.

\section{Automation levels in the production lines}

The level of automation was evaluated the production lines called: 1) control and supervision, 2) operational-process, 3) communication, focused on the areas of the process for 1) supply of materials, 2) production process, 3) warehouse and 4) dispatch logistics.

\section{Control and supervisión}

For the automation focused on the supply of materials and the productive process, a respective general score was obtained in the seven companies of $50 \%$, which implies that supervision uses equipment and tools for the control type (ON-OFF). For the area of packaging and packaging, Warehousing and Logistics dispatch was determined that they do not have automation.

\section{Process-operation}

The automation focused on the supply of materials, indicates that $25 \%$ of the operator uses equipment and tools to perform the operations. While for the Production-Process, it is recorded that it is $50 \%$, which implies that the supervisor uses equipment and tools for the control type (ON-OFF). For the area of packaging and packaging, Warehousing and Logistics dispatch it was determined that there is $50 \%$ automation for each area, and equipment and tools are used for control type (ON-OFF).

\section{Comunication}

The automation in communication, in the area of material supply, obtained 50\%, which implies that supervisor uses equipment and tools for the control type (ON-OFF). While for the production process, packing and packaging, storage, and logistics of dispatch was $75 \%$, which indicates that these three areas, operators operate advanced controllers to perform their work. Therefore, it was found that in the area of communication there is the greatest use of automation, followed by the production process and the supply of materials. 


\section{Acknowledgment}

This project was funded by TECNM / I.T.Ensenada, in the call for support for scientific research projects 2018 .

\section{Conclusions}

Of the seven companies that were evaluated, it was identified that, for decisions on the purchase of new technology, including automation, they are carried out through the legal representative and the board of directors. Without operations management and maintenance area being considered. The purchase process is preferably carried out through previous suppliers.

$71.43 \%$ companies interviewed carry out automation projects focused on the production process and the supply stage. For technological surveillance, companies turn to the internet, participate in fairs and technological missions. Consider the catalogs or the visit of the suppliers, and $28.57 \%$ resort to research centers or technology transfer. Only $14.29 \%$ take into account customer information and none consider patents.

As for the company-academy link for the development of technological projects, companies that participate with academic centers were registered and a company has its own research center on the part of the corporate and three companies have no link with the academy. Automation in companies, stands out in the area of communication, followed by the production process and the supply of materials.

\section{References}

CIDEM (Centro de Innovación y Desarrollo Empresarial). (2002). Guía de gestión de la innovación. Universidad de Cataluña, Barcelona, España.

Hualde, A., Carrillo, J., y Domínguez R. (2011). Diagnóstico de la industria aeroespacial en Baja California. Características productivas y requerimientos actuales y potenciales de capital humano, Proyecto Fondo Mixto Baja California 22601 Convocatoria 2005. Disponible: http://www.colef.mx/jorgecarrillo/wp-

content/uploads/2012/04/PU314.pdf
Mandujano, H., Romero-Samaniego, E., Ovalle, M., Sibaja, T., Cervantes-Trujano, M. 2019. Número Especial de la Revista Aristas: Investigación Básica y Aplicada. ISSN 20079478. Vol.7, Núm. 14. Año 2019. Pp. 447-450

Moreno, G. (2001). Automatización de procesos Industriales. México: Editorial Alfa Omega.

Ovalle, A. M; Ocampo, O.L y Acevedo, T.M. (2013). Identificación de brechas tecnológicas en automatización industrial de las empresas del sector metalmecánico de Caldas, Colombia. Revista Ingeniería y Competitividad, Volumen 15, No. 1, p. $171 \quad-182$.

Piedrahita, R. (2001). Ingeniería de la automatización industrial. Bogotá: Editorial Alfa

Omega.

ProMéxico, (2015) "National Flight Plan: Mexico's aerospace industry road map". Executive Direction of Prospective Analysis, Business Inteligence Unit, Disponible: http://www.promexico.gob.mx/documentos/ma pas-de-ruta/Roadmap-Aerospace-2015.pdf.

Sarachez, Cárdenas y Giraldo. (2005). Procedimiento para la definición y jerarquización de prioridades competitivas de fabricación: aplicaciones en la industria metalmecánica. Revista Ingeniería y Competitividad., Volumen 1 No. 2, p. 84-91. 